\author{
Sh. Kalbergenova ${ }^{1}$, B. Sansyzbayeva ${ }^{2}$, B. Koshkarbayeva ${ }^{3}$ \\ ${ }^{1}$ Almaty University \\ ${ }^{2,3}$ Kazakh National Women's Teacher Training University \\ Kazakhstan, Almaty
}

\title{
ACTIVE TEACHING METHODS AND THEIR PLACE IN THE EDUCATIONAL PROCESS
}

\section{Abstract}

Historically, the oldest group of methods are verbal and then written methods. It should be noted that in the early years of the formation of the theory and practice of teaching in the Soviet school, a large place, if not the most important thing, was assigned to active teaching methods - heuristic, research, especially excursions, laboratory, practical research. Teaching methods are the most important structural components of a holistic pedagogical process, which includes the goals and objectives of training, the content, the forms of organization of training and its results. As you know, the main characteristic of the learning process is its purpose, on which the choice of the content of education (training material) depends. The teaching methods should correspond to this content.

Key words: English, pedagogical technology, teacher, methods, education

$$
\begin{gathered}
\text { Ш. Калбергенова }{ }^{1} \text {, Б. Сансызбаева }{ }^{2} \text {, Б. Кошқарбаевна } \\
{ }^{1} \text { Алматы университеті, } \\
{ }^{2,3} \text { Қазақ ұлттық қыздар педагогикалық университеті, } \\
\text { Қазақстан, Алматы }
\end{gathered}
$$

\section{КӘСІПТІК БІЛІМ БЕРУГЕ АҒЫЛШЫН ТІЛІ САБАҚТАРЫНДАҒЫ ҚАЗІРГІ ЗАМАНҒЫ ПЕДОГОГИЯЛЫҚ ТЕХНОЛОГИЯЛАР}

\section{Аңъдатпа}

Әдістердің тарихи ең ескі тобы - ауызша, содан кейін жазбаша әдістер. Кеңес мектебінде оқытудың теориясы мен тәжірибесінің қалыптасуының алғашқы жылдарында, ең маңыздысы болмаса, оқытудың белсенді әдістері - эвристикалық, зерттеушілік, әсіресе экскурсиялық, зертханалық, практикалық зерттеулер жүргізілгенін атап өткен жөн. Оқыту әдістері тұтас педагогикалық үдерістің маңызды құрылымдық компоненттері болып табылады, онда оқытудың мақсаты мен міндеттері, мазмұны, ұйымдастыру формалары және оның нәтижелері кіреді. Оку процесінің негізгі сипаттамасы оның мақсаты болып табылатыны белгілі. Оқыту әдістері осы мазмұнға сәйкес болуы тиіс.

Түйінді сөздер: ағылшын тілі, педагогикалық технологиялар, мұғалім, әдістеме, білім

$$
\begin{gathered}
\text { Ш. Калбергенова }{ }^{1}, \text { Б. Сансызбаева }{ }^{2,}, \text { Б. Кочкарбаевна }{ }^{3} \\
{ }^{1} \text { Университета Алматы, } \\
{ }^{2,3} \text { Казахского Начионального Женского Педагогического Университета, } \\
\text { Казахстан, Алмать }
\end{gathered}
$$

\section{АКТИВНЫЕ МЕТОДЫ ОБУЧЕНИЯ И ИХ МЕСТО В ОБРАЗОВАТЕЛЬНОМ ПРОЦЕССЕ}

\section{Аннотация}

Исторический самая старая группа методов - это словесные, а затем письменные методы. Следует отметить, что в первые годы становления теории и практики преподавания в советской школе большое место, если не самое важное, отводилось активным методам обучения эвристическим, исследовательским, особенно экскурсионным, лабораторным, практические 
исследования. Методы обучения являются важнейшими структурными компонентами целостного педагогического процесса, который включает в себя цели и задачи обучения, содержание, формы организации обучения и его результаты. Как известно, основной характеристикой учебного процесса является его назначение, от которого зависит выбор содержания обучения (учебного материала). Методы обучения должны соответствовать этому содержанию.

Ключевые слова: английский язык, педагогические технологии, учитель, методика, образование

Introduction. The teaching method performs important functions in the learning process: with its help, the content of the subjects studied is transferred to the students, the cognitive activity of the students is controlled, the students develop intellectually and the necessary personal qualities are formed. The method also performs the stimulating, communicative, diagnostic and correctional functions necessary for the normal functioning of the educational process.

There is no strictly scientific classification of teaching methods in didactics, since science cannot yet find one basis for distinguishing all methods. Therefore, there are several classifications for various reasons:

1.By source of knowledge. Verbal: story, lecture, conversation, discussion. Visual: Demonstration, Illustration. Practical: exercise, laboratory work, practical work

2.By the nature of cognitive activity: explanatory - visual (reproductive), problematic presentation, partially search (heuristic), research

3.For didactic purpose: methods for studying new knowledge, methods for consolidating knowledge, methods of control.

4.By place in the structure of activities

In the educational process of educational institutions, the search and use of new methods of activating students in the learning process has been observed since the $60 \mathrm{~s}$. XX century and to the present. Initially, the development of these methods is the destiny of individual experimental teachers. Today, most ordinary teachers do this. The cognitive activity of the student is expressed in a steady interest in knowledge, in a variety of independent educational activities. With regard to many methods, disputes and discussions continue, but they nevertheless exist, and their number is increasing every day.[1, p. 25]

Methods.In the implementation of the goals of problem-based learning are active methods. The systematic foundations of active teaching methods began to be widely developed in the second half of 1960 and in the early 1970s in the studies of psychologists and educators. A major role in the formation and development of active teaching methods was the work of M. M. Birshtein, T. P. Timofeevsky, I. M. Syroezhkina, S. G. Gidrovich, R. F. Zhukova, V. N. Burkova, B. N. Khristenko, A. M. Smolkin, V. M. Efimov, V. F. Komarov and others. Application in practice of the problematic learning and developmental learning led to the emergence of methods called active. In the traditional learning process, the student plays a "passive" role: listening, memorizing, and reproducing what the teacher gives. This forms knowledge at the level of acquaintance and develops the student little. One of the ways to activate the student is new systems, technologies and teaching methods. The student's activities are productive, creative, search character in these teaching methods. The methods are based on the dialogue interaction between the teacher and the student. A.M. Matyushkin, T.V. Kudryavtsev, M.I. Makhmutov, I. Ya Lerner, M.M. Levy and others contributed to the development of active teaching methods.

Active teaching methods can reduce the time spent on the development of knowledge and the formation of skills. Since the assimilation of knowledge, mastery of practical working methods and development of skills is carried out simultaneously, in one process of solving problems, analyzing situations or a business game.[2, p. 35]

Thus, active teaching methods are methods of enhancing educational and cognitive activity that encourage active mental and practical activity in the process of mastering the material when not only the teacher is active, but also the students are active. Active teaching methods involve the use of such a system of methods, which is aimed mainly not at the presentation of ready-made knowledge and its reproduction, but at independent mastery of knowledge in the process of active cognitive activity. Thus, active learning methods are learning by doing.

Active teaching methods are divided into two types. Active teaching methods of the first type include problem lectures, problem-active practical classes, seminars and discussions, training and monitoring programs, conferences, Olympiads, etc. All of them are focused on the student's independent activity and problematic nature. 
Active teaching methods of the second type - imitation - are divided into non-game and game. Nongame active teaching methods include the method of analysis of specific situations, simulators, simulation exercises to find a known solution. [3, p. 56]

Active gaming teaching methods include business (managerial) games, role-playing method, individual game classes on models. These methods are highly effective in the educational process. The most difficult are the game active learning methods.

As for the classification of didactic games, there are a great many of them developed today, but there are no unified approaches.

The brainstorming method (brainstorming) involves engaging in knowledge by jointly solving a difficult problem.

In the classes when using this method of work, students are divided into groups of 4-6 people, in which the roles of students (leader, conservator or critic, analyst, innovator, etc.) are, determined in advance, according to which these students work. All groups can solve a single task for all or several different tasks. After a certain time, the groups must present their collective decision. Criticism of the proposed solutions is not allowed, but it is allowed to supplement and develop ideas expressed by other students.

Close to the brainstorming method is the problem learning method, which can also be widely used by the teacher. Its essence is to create a problem (contradictory) situation, allowing students to more deeply know processes, phenomena, and objects. It should be remembered that the teacher for students creates the problem (contradiction), that is, it is only for children.

In itself, the educational problem situation must necessarily cause intellectual difficulties for students.

Some didactics see the disadvantage of this method in the large time costs. However, these costs more than pay off.

Result.From the foregoing, it follows that the goal of active teaching methods is that all mental processes (speech, memory, imagination, etc.) participate in the assimilation of knowledge, skills. The teacher in his professional activity uses the classification and the group of methods that most fully help the implementation of the didactic tasks that he poses before the lesson. In addition, active teaching methods are one of the most effective means of involving students in educational - cognitive activities. [4, p. 28]

The teaching of English in MCOU "Little - Kaminski Secondary School" began in 2009 in grades 2 and 5. The children came to the first lessons with great joy, but gradually the interest in learning the language began to fade. Teachers and parents understand the importance of learning a foreign language, but for children this is not motivation. English is a difficult subject to study, therefore we need to constantly maintain interest in the subject, and in order to maintain interest, we need to constantly improve working methods. As a primary school teacher, it is clear to me that the games are of great help in solving these issues. Their use gives good results, increases the interest of children in the lesson, and allows them to focus on the main thing - mastering speech skills in the process of a natural situation, communicating during the game.

The place of the games in the lesson (as well as any active method) and the time allotted depend on a number of factors: the preparation of the students, the material being studied, the goals and conditions of the lesson, etc. For example, if the game is used as a training exercise for initial fastening, then it can allow 20-25 minutes of the lesson. In the future, the same game can be carried out by repeating already completed material. The same game can be used at different stages of the lesson. [5, p. 46]

Discussion.It should be remembered that with all the attractiveness and effectiveness of games, it is necessary to observe a sense of proportion;otherwise, they will tire students and lose the freshness of the emotional impact.

The following categories of games are distinguished in the English lesson

1.lexical games;

2.grammar games;

3.phonetic games;

4.spelling games;

5.creative games.

However, it should be noted that in most cases several categories are combined in a game - I use lexico-grammar, lexico-spelling, grammar-creative and many other games in my work.

Games in foreign language lessons can and should be used to relieve tension, monotony, while practicing language material, and enhancing speech activity. 
At the beginning of the lesson, it is advisable to conduct phonetic games, the purpose of which is to set the correct articulation of students' speech organs when pronouncing individual English sounds.

For example, a prankster comes to us for English lessons - a monkey who grimaces and asks the children to repeat after her what they willingly do.

"... The monkey smiled broadly, and then pouted her lips again ..."

"... The monkey went for a walk in the woods, but it was cold outside, her legs were frozen, she began to breathe on them to warm them (sound training h) ..."

"... After a walk in the woods, the monkey got a sore throat, she came to the doctor, but cannot say her name, and she only gets $\mathrm{m}$ (training sound $\mathrm{m}$ ) ..."

This game can be conducted on a specific lexical topic and as a transitional stage from a phonetic warm-up to the study of a new topic. Another version of the game when children from a long word are short. In addition, my children really like to solve crossword puzzles in the classroom (this can take a few minutes at the end of the lesson, and the result is high). First, you can guess the crosswords where the translation of the Russian word is written, then the task can be complicated, first the children must solve the riddle, and then enter the guessing word into the cells of the crossword puzzle. [6, p. 23]

To practice lexical skills, you can also play various variations of lotto. For example: when studying the letters of the alphabet, you can give children cards, one is written in a capital letter, the other a small one. It is necessary to combine the letters. Alternatively, give a cut word by syllables or by letter, children must make up the word.

Another interesting lexical game is Snowball. Learning each other call different words on one topic, and each subsequent should repeat everything that he heard and add his own word. The winner is the one who can "roll" the largest lump, that is, repeat more than all the words.

A separate group is occupied by grammar games. In elementary school, children sometimes do not know the names of speech parts and sentence members in Russian, so it is also advisable to teach English grammar through the game.

As for creative games, their choice is limited only by the imagination of the teacher and his students. Here may be the manufacture of various creative products, and various role-playing games, stage plays, theatrical productions. [7, p. 59]

Conclusion.This, of course, is not a complete list of games used in English classes in elementary school: it can be replenished indefinitely. The game may be planned, or it may be improvisation. We must remember that the game is only an element of the lesson, and it should serve the achievement of the didactic goals of the lesson. Therefore, it is necessary to know exactly what skill, skills are trained in this game, what the child did not know how to do before the game and what he learned during the game. [8, p. 40]

References:

1) AmonashviliSh.A. Personality-humane basis of the pedagogical process: a tutorial. MN: 2003. $234 p$.

2) Bim I.L. Personality - oriented approach - the basic strategy of school renewal. Foreign languages in school. - 2002.- №2

3) Velikanova A.V. Competence-oriented approach to education. Samara: Profi, 2007.-92s.

4) Galskova N.D., Gez N.I. Theory of learning foreign languages. Lingvodidactic and methods: a tutorial. M.: Academy, 2007. - 336s.

5) Zimen I.A. Pedagogical psychology: a textbook for high schools. M.: Logos, 2003.-287 p.

6) Selevko G.K. Modern educational technology. M.: Academy, 2008. - 346s.

7) Smirnova S.A. Pedagogy: theories, systems, technologies. M.: Academy, 2008. - 352 p.

8) Filatov V.M. Methods of teaching foreign languages in primary and basic secondary school: a training manual. Rostov n/a: Phoenix, 2004. - 416 p. 